\title{
Independent inquiry needed into firing of whistleblowers
}

A Manitoba senator is pressing Prime Minister Paul Martin for an independent inquiry into Health Canada's decision to fire 3 scientists who have publicly criticized the department's drug review policies.

Shiv Chopra, Margaret Haydon and Gérard Lambert, who reviewed veterinary drugs, were fired July 14 while on stress leave from the department. All 3 have spoken out publicly about the department's drug approval process and what they call the "undue influence" of the phar+ maceutical industry.

$\exists$ "I know these scientists to be dedicated public servants who placed their devotion to the protection of public health and

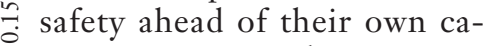
reers," Mira Spivak wrote in a Љ July 15 letter to Martin. "They are whistleblowers who were ultimately shown to be correct in their scientific concerns."

Spivak has asked Martin and Health Minister Ujjal Dosanjh to stay the scientists' dismissals "pending an independent inquiry into their conduct and the conduct of Health Canada managers regarding their work."

Health Canada spokesman Ryan Baker said the scientists' termination was "not because of anything they may have said publicly."

Letters sent to the scientists at home stated that they had not completed drug review files and were being fired on that basis, Chopra said.

But the scientists, who have filed a grievance with the Public Service Alliance of Canada, believe they were fired because of their past whistle-blowing activities, particularly around Monsanto Canada's application for approval of a bovine growth hormone. The scientists testified before the Senate Agriculture Committee about their safety concerns regarding the Monsanto drug.

Spivak, who sat on that committee, noted that the 1999 committee report related the scientists' fear of reprisals. The senators asked the scientists to contact them if they felt they were suffering as a result of their testimony.

Conservative MP Pierre Polievre (Nepean-Carleton), who represents the riding where 2 of the scientists live, is also calling for an inquiry and has promised to raise the issue when Parliament reconvenes in October. - Laura Eggertson, CMAJ

\section{Medicolegal}

\section{Cross-border malpractice coverage cancelled}

After more than a decade of warning members about the litigation risks of treating Americans, the Canadian Medical Protective Association (CMPA) 千 will no longer cover doctors who willingly take them on. The association cites an "unstable" insurance situation in the United States as a major impetus for this policy.

"The costs of settling or even defending these cases is now so

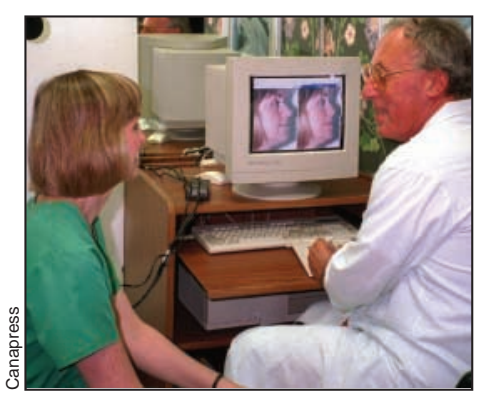

Dr. Harold Silver says Americans are attracted to his Toronto clinic becausee of lower surgery costs and Canada's stellar health care reputation. high that we're seeing many medical malpractice insurers in the United States either abandoning the market or driving up their premiums to the point where physicians can't afford malpractice insurance," says Dr. John Gray, CMPA executive director and $\mathrm{CEO}$.

The American Medical Association has declared 20 states "in crisis" because insurance costs have driven physicians away, compromising health care.

"Despite our ... warnings to members about avoiding legal actions, we saw more and more members who actually were ... increasing their exposure by actively soliciting American patients," says Gray.

American clients seek lower prices for procedures such as cosmetic surgery in Canada.

The CMPA's new policy, which came into effect in January 2004, applies only to elective procedures. Doctors treating
non-Canadians in cases of emergency, or for humanitarian reasons, will still be covered.

Vaughan Black, a University of Dalhousie law professor, has studied cases of damage compensation across the US-Canada border. The CMPA's concerns appear to be justified, he says. While he knows of no crossborder medical malpractice suits, a Supreme Court decision late last year (Beals v. Saldanha, 2003) upheld the major damages a US court awarded against a defendant in Canada involved in a real estate dispute here.

Black suggests the Supreme Court decision would limit the ability of Canadian courts to refuse medical malpractice settlements.

The CMPA provides members with unlimited coverage, which may be an enticing target for US litigants, says Gray. "A single legal action could wipe out CMPA's reserves." - Tim Lougheed, Ottawa 